

\title{
De Tweede Wereldoorlog in de
}

\section{Lage Landen}

\section{Bedenkingen bij vijftig jaar oorlogshistoriografie in de BMGN}

\author{
NICO WOUTERS
}

De evaluatie van vijftig jaren kopij over de Tweede Wereldoorlog in de BMGN - Low Countries Historical Review (BMGN) levert een rijk maar eenzijdig beeld op. Vooral het feit dat de Belgisch-Nederlandse uitwisseling nooit echt van de grond kwam, mag gezien het oorspronkelijke doel van de BMGN een gemiste kans worden genoemd. Helemaal onlogisch is het echter niet: de Belgische en Nederlandse woIl-geschiedschrijving kenden uiteenlopende nationale ontwikkelingen. Zeker de paradigmatische kaders ontwikkelden zich anders en hadden uiteindelijk zelfs tegengestelde effecten: van een situatie van scherpe polarisering in Nederland tot makke consensus in België. Dat maakt een Belgisch-Nederlands gesprek niet vanzelfsprekend. We bedoelen misschien ongeveer hetzelfde met het begrip 'accommodatie', maar de specifieke ladingen die dat begrip heeft gekregen, zijn intussen helemaal anders. De concrete voorwaarden creëren voor een Belgisch-Nederlandse uitwisseling binnen dit onderzoeksveld blijft dus een werf, ook voor de BMGN. Deze interactie zou beide nationale historiografische tradities wellicht verrijken.

The evaluation of fifty years of copy about World War II in the BMGN - Low Countries Historical Review (BMGN) yields a rich but one-sided impression. That the BelgianDutch exchange never truly got under way may, given the original goal of the BMGN, be considered a missed opportunity. All the same, this is not entirely illogical: Belgian and Dutch woll historiography followed divergent national trajectories. Especially the paradigmatic contours emerged differently and ultimately even brought about contradictory effects, from deep polarisation in the Netherlands to meek consensus in Belgium. This does not make a Belgian-Dutch dialogue selfevident. We possibly may use the concept 'accommodation' with a similar meaning, but the specific connotations that the concept has acquired are by now entirely 
different. Bringing about the concrete conditions for a Belgian-Dutch exchange within this research field is therefore an ongoing project, even for the BMGN. Such interaction would surely enrich both national historiographic traditions.

De oogst van vijftig jaren kopij over de Tweede Wereldoorlog (woII) in de BMGN kan 'rijk maar eenzijdig' worden genoemd. ' Ik telde 38 volwaardige artikelen over woII stricto sensu, met als meest voorkomende thema's de Nederlandse woII-historiografie (elf artikelen), de Shoah (acht artikelen) en de collaboratie en zuivering (vijf artikelen). ${ }^{2}$ De meeste bijdragen waren van de hand van Nederlandse auteurs, zes artikelen werden door Belgische auteurs geschreven en slechts één artikel had een Belgisch-Nederlands comparatieve opzet. ${ }^{3}$ Ondanks het feit dat het stimuleren van debat één van de hoofdopdrachten was bij de lancering van het tijdschrift, kwamen discussiedossiers en fora over woIr maar traag op gang. ${ }^{4}$ Het eerste 'debatstuk' over woII dateert uit 1986 en de drie daaropvolgende woII-discussiebijdragen moest men zelfs bij Belgische historici gaan zoeken. ${ }^{5}$ De BMGN profileerde zich de eerste twee decennia dus niet als een debatforum over onderwerpen die men had kunnen verwachten, zoals het werk van Loe de Jong, de institutionele positie van het NIOD, het onderzoek over nationale 'schandalen', de verruiming van woII-onderzoek, specifieke controversiële publicaties en woII-herdenkingen of collectieve herinneringen.

Afkortingen: BMGN: Bijdragen en Mededelingen betreffende de Geschiedenis der Nederlanden, BMGN/LCHR: Bijdragen en Mededelingen betreffende de Geschiedenis der Nederlanden/The Low Countries Historical Review, BMGN - LCHR: BMGN - Low Countries Historical Review.

2 Het eerste woll-artikel dateert uit 1978 (93:3) en is wat atypisch: een review-artikel van VVD-politicus Harm van Riel over Loe de Jongs boekenreeks Het Koninkrijk [...]. Naast de artikelen die onder te brengen zijn bij deze 'klassieke' thema's, werden ook specifieke casusartikelen gepubliceerd, zoals dat van Hein Jongbloed over het NederlandsSovjetrussische akkoord van 10 juli 1942 (95:3, 1980), Cornelis Wiebes en Bert Zeeman over het Manhattanproject (106:3, 1991), Robert Vonk over de verplichte ziekenfondsverzekering (127:3, 2012), Ralf Futselaar en Ingrid de Zwarte over Nederlands gevangenispersoneel $(129: 3,2014)$ en Christiaan Ruppert over Joodse oorlogstegoeden (130:3, 2015). Het Bernhard-dossier (126:2, 2011) integreerde ik overigens niet in dit overzicht.
3 Wim Meyers over Belgische historiografie (105:2, 1990), Marc Van den Wijngaert over de secretarissen-generaal (105:2, 265-279), Bruno De Wever (118:1, 2003) en Robby Van Eetvelde (124:3, 2009) over de collaboratie in Vlaanderen, Antoon Vrints over de voedselvoorziening in Nederland $(126: 3,2011)$ en Pieter Lagrou over Loe de Jong (130:3, 2015). Jan Julia Zurné en ikzelf vergeleken daderprocessen met betrekking tot de Jodenvervolging $(131: 2,2016)$. Het enige andere internationaal comparatieve artikel nam Frankrijk als andere casus, namelijk Jan Banks artikel uit 2004 over het protestantisme tijdens woII (119:4).

4 'Een woord ter inleiding', BMGN 85:1 (1970) 4-5. DOI: https://doi.org/10.18352/bmgn-lchr.1599.

5 Rudi Van Doorslaer en Juul Verhelst in 1987 over (dis)continuïteit in de Belgische wollgeschiedenis (102:4), Adriaan Verhulst in 1991 over de katholieke Vlaamse beweging en de collaboratie (106:2) en Gustaaf Janssens in 1998 over buitenlandse politiek van België op de vooravond van de Duitse inval (113:4). 
In algemene zin lijkt duidelijk dat de woII-publicaties in de BMGN niet het gevolg zijn van een bewust redactiebeleid, maar van een duurzame stroom aan individuele artikelen. De BMGN publiceerde slechts één volwaardig woII-themanummer, namelijk dat uit 1981 over het bevrijde zuiden van Nederland $(96: 2,1981)$. Dat was vooral het initiatief van Ad Manning, voorzitter van de raad van bestuur van het toenmalige Rijksinstituut voor Oorlogsdocumentatie (RIOD), die aan de Universiteit van Nijmegen een onderzoeksprogramma over de overgangsperiode had gelanceerd. ${ }^{6}$ Met wat goede wil kan ook het woII-nummer uit 1990 dat verscheen naar aanleiding van vijftig jaar Duitse inval in Nederland als een themanummer worden beschouwd. ${ }^{7}$ Dit nummer, met ook enkele Belgische bijdragen, bestond echter uit losstaande artikelen en illustreerde als dusdanig vooral hoe moeilijk het blijkbaar was een homogeen woII-themanummer samen te stellen.

Het is niet onlogisch dat de BMGN zich in een afwachtende modus plaatste waar het woIr betreft. Bij veel redactieleden was er misschien de veronderstelling dat dit soort onderzoek thuishoorde in de gespecialiseerde Belgische en Nederlandse woII-vaktijdschriften. ${ }^{8}$ Misschien werd woII als minder bruikbaar beschouwd in de reflecties binnen de BMGN over wetenschappelijke vernieuwing: in de meer conceptuele themanummers of discussiedossiers van de afgelopen twintig jaar bleek woIr als casus meestal afwezig. ${ }^{9}$ Maar wellicht overheerste bovenal het gevoel aan de opeenvolgende de naoorlogse spanning tussen 'vernieuwers' en 'herstellers'. In zijn inleiding pleit Manning in 1981 voor meer aandacht in woll-onderzoek voor economische geschiedenis, voor de 'psychologische' geschiedenis van het dagelijks leven en voor vergelijkende microstudies over machtsorganisatie en verzuiling. Aanleiding is de verjaardag van vijftig jaar Duitse inval in Nederland, maar tegelijk ook het afsluiten van Loe de Jongs reeks Koninkrijk. Helaas is dit nummer van BMGN $(105: 2,1990)$ geen volwaardige academische beschouwing op dat werk geworden. Buiten de wat strategischbescheiden 'zelfkritiek' van De Jong, gebaseerd op zijn voordracht op de jaarvergadering van het Nederlands Historisch Genootschap van 21 oktober 1988, en een bespreking van De Jongs laatste twee delen door Hans Blom, publiceert dit nummer waardevolle maar helemaal loshangende artikelen waaronder van twee Belgen: Mark Van den Wijngaert schrijft over zijn doctoraatsonderzoek en Wim Meyers van het Navorsings- en Studiecentrum van de Geschiedenis van de Tweede Wereldoorlog (NSGwo, het latere CegeSoma) publiceert over de Belgische historiografie. Ook de recensierubriek in dit nummer staat helemaal in het teken van woll.

8 In Nederland het (na onder meer een reeks Studies en Cahiers) door het RIOD vanaf 1989 uitgegeven jaarboek Oorlogsdocumentatie '40-'45 en in België de Bijdragen tot de Geschiedenis van de Tweede Wereldoorlog (1970-1995) en de opvolger Bijdragen tot de Eigentijdse Geschiedenis (19962011).

9 Eigenlijk valt hieronder enkel het artikel van Ido de Haan over het Nederlandse Holocaustonderzoek in het themanummer over de internationale relevantie van de Nederlandse geschiedschrijving (125:2-3, 2010). De Haan beargumenteert dat de Holocaust in Nederland best wordt bestudeerd als een nationale variant op een internationaal genocidair programma en dus niet vanuit een soort vooropgesteld Nederlands 'exceptionalisme'. 
redactietafels dat het niet altijd over de oorlog moest gaan. Tijdens mijn eigen passage in de redactie (2012-2018) proefde ik alleszins een getemperd enthousiasme over woII. In een breed tijdschrift als de BMGN kan deze periode al snel ervaren worden als dat lastige kind dat zich telkens naar de voorgrond elleboogt op de dag van de klasfoto: het kind is welkom maar extra aanmoediging verdient het niet. En inderdaad bleek dat de woIr-kopij best voor zichzelf kon zorgen.

\section{Wat met de Lage Landen?}

Deze houding leidde zoals gezegd in de BMGN wel tot een wat eenzijdige oogst: in de bijdragen domineren klassieke thema's met een overwicht voor politieke geschiedenis of socio-economische geschiedenis. Er is zeer weinig cultuurgeschiedenis (in de meest ruime zin) en weinig conceptuele vernieuwing of verruiming waarbij woII in een langer chronologisch of een transnationaal kader wordt geplaatst. Ook het auteursbestand is opvallend eenzijdig. Van de 54 auteurs in mijn overzicht waren er zeven vrouwen. De geschiedschrijving van wOII in de BMGN was een zaak van gevestigde mannen van middelbare leeftijd die niet zelden een NIOD-band hadden. Loe de Jong en Hans Blom bleken erg aanwezig, nog meer als paradigmatische begrippen dan als auteurs.

Men kan argumenteren dat de BMGN zo de opdracht heeft vervuld. Maar toch liet het tijdschrift vanuit zijn missie één kans liggen, namelijk op het terrein van de Belgisch-Nederlandse reflectie en uitwisseling. Het is misschien geen verrassing dat echte Vlaams-Nederlandse comparatieve artikelen over woII zeldzaam zijn, maar dat ook in de debatrubrieken deze uitwisseling zelden van de grond komt, is dat wel. Er waren al die tijd immers goede contacten tussen de Nederlandse en de Belgische onderzoekers, maar de Belgische auteurs - en dat zijn altijd Vlamingen - die over woII publiceerden in de BMGN deden dat vaak in eigen onderonsjes (enkele uitzonderingen niet te na gesproken), zoals bijvoorbeeld in het discussiedossier over Lode Wils' trilogie Honderd jaar Vlaamse beweging (106:2, 1991). ${ }^{10}$

Hoewel de roep naar diverse vormen van 'verruiming' van het woIIonderzoek al decennia kan rekenen op instemmend applaus vanop alle banken, een Belgisch tijdschrift kunnen gepubliceerd worden. De vrijzinnige historici Adriaan Verhulst (UGent) en Els Witte (VUB) beargumenteren in essentie dat Wils de collaboratie en naoorlogse bestraffing ervan te eenzijdig interpreteert vanuit de tegenstelling katholiek-vrijzinnig. Het toen net verschenen iconische boek van Luc Huyse en Steven Dhondt (net als Wils van de ku Leuven) over de naoorlogse bestraffing van collaboratie kon al wel in deze discussie meegenomen worden, maar het in 1994 te verschijnen boek van Bruno De Wever (UGent) over de Vlaamsnationale collaboratie nog niet. Luc Huyse en Steven Dhondt, Onverwerkt verleden. Collaboratie en repressie in België, 1942-1952 (Leuven 1991); Bruno De Wever, Greep naar de macht. Vlaamsnationalisme en Nieuwe Orde: het VNV 1933-1945 (Gent/Tielt 1994). 
kwam een reflectietraject daarover in het kader van de 'Lage Landen' alleszins niet in de BMGN aan bod. Dat ligt uiteraard voor een groot stuk aan de moeilijk te doorbreken nationale inbedding en oriëntatie van het woII-onderzoek zelf. Terwijl bij veel historisch onderzoek de Belgisch-Nederlandse uitwisseling intrinsiek deel uitmaakt van het onderzoekveld, is dat voor het onderzoek naar de bezettingstijd toch anders. Het bleek de afgelopen decennia naïef te denken dat zinvolle Belgisch-Nederlandse uitwisseling rond woIr 'automatisch' plaatsvindt wanneer je specialisten uit de Lage Landen samenbrengt. Dat bleek ook uit het moeizame internationale KNHG-voorjaarscongres uit 2015, dat ondanks de ambitieuze titel 'Towards a new history of WwI?' het potentieel niet kon vervullen. Vanuit de premisse dat die Belgisch-Nederlandse uitwisseling in de toekomst de missie van de BMGN blijft, bekijk ik of vijftig jaren aan woIIkopij, en de lacunes daarin, handvaten bieden voor een verruiming in die zin.

\section{Academische polarisering in Nederland}

Eén aspect dat een uitwisseling binnen het kader van de Lage Landen misschien in de weg stond, zijn de nationaal sterk verschillende paradigma's die de deels onuitgesproken krijtlijnen vastleggen waarbinnen een onderzoeksveld zich heeft ontwikkeld. Het gaat hier over de ontdekkingscontext zeg maar; hoe onderzoekers zich begripsmatig oriënteren en hoe deelnemers aan een debat zich tegenover elkaar opstellen. Daarin verschillen België en Nederland grondig en ik start hiermee omdat dit één van de weinige rode draden is die consistent in de woII-kopij van de BMGN naar boven kwam.

Voor Nederlandse woII-onderzoekers blijft dat in belangrijke mate gaan om een positiebepaling tegenover de discussie over de didactische ordening uit Loe de Jongs Het Koninkrijk der Nederlanden in de Tweede Wereldoorlog (1969-1988). Die ordening betekende in essentie dat de wetenschappelijke vraagstelling, structuur en analyse zich oriënteren op de grote ijkpunten 'collaboratie', 'verzet' en 'onderdrukking'. De Jongs opvoedkundige doelstelling gaf deze ijkpunten bovendien een krachtige morele lading. Door het 'staatsmandaat' van De Jongs werk en het uitzonderlijke belang van woIr in het Nederlandse historische bewustzijn kon die ordening ervaren worden als een dwingend keurslijf.

Hoewel de Groningse historicus en eerste voorzitter van de BMGNredactie Ernst Kossmann samen met onderzoekers zoals de Utrechtse historicus Hermann von der Dunk en de Leidse historicus Ivo Schöffer al vroeg vragen stelden bij De Jongs ordening, werd de vroegste basis voor een alternatieve visie voorzichtig naar voor geschoven door de mediëvist Adolf Cohen in $1952 .{ }^{11}$ Hij pleitte ervoor de geschiedenis van woII te integreren 
in de algemene Nederlandse geschiedenis en dus ook internationale wetenschappelijke tendensen te volgen. Dit pleidooi voor wetenschappelijke 'normalisering' van het woII-onderzoek impliceerde dat het onwenselijk zou zijn dat woIr in de toekomst een soort politiek-morele uitzonderingspositie in het nationale historische bewustzijn zou krijgen, maar dat werd toen nog niet ten volle opgemerkt.

De inaugurale rede In de ban van goed en fout? van de Amsterdamse historicus en latere NIOD-directeur Hans Blom in 1983 pikte in zekere zin die draad van Cohen op. Nu De Jong zijn werk afrondde, bepleitte Blom dat de tijd rijp was diens categorisatie te doorbreken. Blom schoof onder meer het aan Kossmann ontleende begrip 'accommodatie' naar voor, als diversifiërend alternatief voor 'goed' en 'fout'. Hij stelde concreet voor onderzoek te verrichten naar de opinies in bezet Nederland, de hoge mortaliteit van Joden in Nederland in internationaal comparatief perspectief en het plaatsen van woII binnen een breder chronologisch kader. Het getuigt van het belang van deze rede dat het allereerste debatstuk over woII in de BMGN in 1986 (101:3) van Cohen zelf kwam, op dat moment adjunct-directeur van het NIOD, die de redevoering van de Rotterdamse mediahistoricus Jan Bank (Oorlogsverleden in Nederland, 1983) en die van Blom onder de aandacht wilde brengen. Cohen benadrukte vooral Bloms suggesties voor nieuw onderzoek en riep de toekomstige redactie van de BMGN op om binnen twintig jaar - dat zou dus in 2003 zijn geweest - Bloms programma te evalueren. ${ }^{12}$

Die evaluatie dook daarna wel op, maar slechts onderhuids in drie kort opeenvolgende historiografische overzichten: dat van Peter Romijn naar aanleiding van veertig jaar bevrijding (102:2, 1987), van David Barnouw naar aanleiding van vijftig jaar inval $(107: 2,1992)$ en tot slot van Marton van Hennik in de context van vijftig jaar bevrijding $(111: 4,1996)$. Steunend op een omvangrijk literatuuroverzicht concludeerde Romijn dat de oproep van Blom in de praktijk wel degelijk ingang had gevonden. Romijn bespeurde een 'stilzwijgende kentering' door nieuw onderzoek te signaleren dat aansloot bij Bloms suggesties. Barnouw volgde een meer klassieke recensie-aanpak waarbij hij de door hem bestudeerde werken op een scherpe en soms ironische toon duidt ('Het is niet mis om in zeventig bladzijden de collaboratie in Nederland proberen te vatten. Het is L. Mok dan ook niet gelukt'). Hij leek impliciet te besluiten dat er weinig grote verschuivingen hadden plaatsgevonden. Van Hennik was meer categoriek: hij oordeelde dat van een echte verschuiving geen sprake was. Hij stelde vast dat de grote meerderheid van de werken uit 1995-1996 gevat kon worden in de vier kernwoorden 'lokale geschiedenis', 'illegaliteit', 'collaboratie' en 'Jodenvervolging'.

van zo'n stand van zaken'. Hans Blom, In de ban van goed en fout. Geschiedschrijving over de bezettingstijd in Nederland (Amsterdam 2007) 156. 
Waar het artikel van Cohen nog onopgemerkt passeerde, ging de rede van Blom een eigen leven leiden. Meer dan als een complementaire wetenschappelijke aanvulling op het werk van De Jong, werd Bloms rede in de daaropvolgende decennia geïnterpreteerd als een soort onverzoenbare morele antithese ervan. Vooral die morele implicaties voedden een geleidelijke polarisering in de Nederlandse woII-geschiedschrijving, die na 2000 ook zijn weg vond naar de BMGN. De term 'accommodatie' beroerde de gemoederen onder Nederlandse woII-experts. Joggli Meihuizens boek over de bestraffing van economische collaboratie bijvoorbeeld vormde de aanleiding voor een discussiedossier in BMGN over 'totale oorlog' (119:4, 2004). ${ }^{13}$ Gezien de complexiteit van het thema kregen we hier een gerichte discussie onder experten. Maar toen de inleider Hein A.M. Klemann de stelling lanceerde dat het analyseren van het normatieve kader uit de strafrechtelijke beoordeling van bedrijfsleiders eigenlijk ook de onwetenschappelijke overname van een morele veroordeling inhield, ontspon zich een feller debat. Klemann lokte hier, me dunkt, doelbewust een discussie uit. Dat hij ondanks zijn naar eigen zeggen zeer positieve appreciatie van het onderzoek van Meihuizen toch meende zo scherp positie te moeten innemen, valt voor mij als Belg op.

Ook in twee andere discussiedossiers van de BMGN uit die periode valt op hoe onvermijdelijk het spook van historisch moralisme in een academisch debat opdook en hoezeer de rede van Blom intussen leek samen te vallen met een 'beweging' waar je willens nillens wel of niet toe behoorde. Het debat over Academische illusies van de wetenschapshistoricus Klaas van Berkel over de Rijksuniversiteit Groningen tijdens de bezetting $(121: 2,2006)$ ging al snel over in hoeverre de morele invulling van het begrip 'academische gemeenschap' ook iets zegt over de waardeoordelen van de auteur zelf. ${ }^{14}$ In dit dossier typeerde Pieter Caljé het boek van Peter Knegtmans over de Universiteit van Amsterdam tijdens de bezetting als een 'Blommiaans' boek. ${ }^{15}$ Over Van Berkels boek schreef hij dat die zich op het eerste zicht 'bij de Blommianen leek aan te sluiten', maar uiteindelijk door zijn eigen moralisme eigenlijk 'het Blommianisme voorbij' ging.

Diezelfde 'onvermijdelijkheid' plaagde ook het discussiedossier uit 2008 (123:3) over twee biografieën over Hans Hirschfeld, secretaris-generaal van onder meer Handel en Nijverheid tijdens de bezetting. De Amsterdamse politicoloog Meindert Fennema - inleider en één van de betrokken biografen kloeg meteen aan dat het in de stukken weer enkel over die vermaledijde

\section{bestraffing van economische collaboratie in}

Nederland na de Tweede Wereldoorlog (Amsterdam 2003).

14

Klaas van Berkel, Academische illusies. De Groningse universiteit in een tijd van crisis, bezetting en herstel, 1930-1950 (Amsterdam 2005).
15 Peter Jan Knegtmans, Een kwetsbaar centrum van de geest. De Universiteit van Amsterdam tussen 1935 en 1950 (Amsterdam 1998). 
oorlog ging. De biografie die John Rhijnsburger en hij hadden geschreven sloot echter te nauw aan bij het paradigmatische debat om niet te worden meegezogen in het zwarte gat. Madelon de Keizer beoordeelde dit boek als een achterhaalde poging om Bloms oratie uit 1983 in de praktijk te brengen. De Amsterdamse historicus Robin de Bruin - terugvallend op het controversiële werk van Gerard Trienekens uit 1995 - zag deze biografie dan weer als teveel aansluitend bij de kritisch-speculatieve visie van De Jong op Hirschfeld. ${ }^{16}$ Met name de innerlijke opvattingen van (de volgens nazi-begrippen 'halfjood') Hirschfeld tegenover de Jodenvervolging stonden in deze discussie centraal.

\section{Een poging tot afstand}

De kers op deze specifieke Nederlandse taart was het BMGN-discussiedossier over Chris van der Heijdens Dat nooit meer. De nasleep van de Tweede Wereldoorlog in Nederland (128:2, 2013). Van der Heijdens boek en dissertatie was in 2011 een soort perfect storm waarin diverse punten van kritiek convergeerden: over methode, gebruik van bronnen en voorbeelden, analysekader en narratieve stijl, de toon en scherpe positionering en wellicht ook de voorgeschiedenis en achtergrond van de auteur. Van der Heijdens vorige boek Grijs verleden (2001) was door critici al gebruikt om aan te tonen waartoe het 'Blommianisme' kon leiden, namelijk een als nefast ervaren moreel relativisme waarin het onderscheid tussen slachtoffers en daders verwaterde. Een 'nivellering' van lijden en verantwoordelijkheid, die bovendien ook wetenschappelijk en historisch niet correct was, zou hiervan het gevolg zijn. Deze discussie bleek een prelude op het bitse debat over Van der Heijdens boek uit 2011, waarin zelfs een term als 'secundair antisemitisme' werd gebruikt.

De BMGN had met toenmalige redacteurs Peter Romijn en James Kennedy twee leden van Van der Heijdens doctoraatscommissie in de rangen. Zij besloten wat afstand te creëren door drie 'buitenstaanders' in het Engels te laten schrijven en Van der Heijden te laten reageren. De in Duitsland werkzame historicus Friso Wielenga vatte in zijn tekst de basiskritiek op Van der Heijdens dissertatie uit 2011 nog eens samen. Wielenga lijkt vooral te suggereren dat Van der Heijdens journalistieke persona zijn academische houding had overwonnen, waardoor de auteur teleologisch schreef en onnodig provocatief chargeerde en daardoor uiteindelijk niet het academische meesterwerk schreef dat er misschien in had gezeten. Bob Moore (Sheffield) en Koen Aerts (UGent) vonden elkaar in hun methodologische kritiek, maar waren al bij al toch vrij positief over het boek. Als buitenstaanders verbaasden zij zich vooral over de felheid van alle reacties. Beiden vonden het Van der 
Heijdens verdienste dat het canonieke beeld over een uniforme nationale woII-herinnering in vraag werd gesteld.

Van der Heijdens reactie in het BMGN-discussiedossier laat mij als buitenstaander wat vertwijfeld achter. Hij pareerde enkele specifieke kritiekpunten op een voor mij sterke manier, maar schreeuwde vooral zijn frustratie uit over het feit dat hij consequent niet begrepen werd. Maar waarom is dat dan, vraag ik me af? Hoewel de vier bijdragen erg boeiende lectuur vormen, zijn ze als geheel toch een gemiste kans: ze brachten ons niet op een volgend punt in deze discussie. Dat laatste werd geillustreerd in de bijdrage van de Groningse historica Barbara Henkes $(125: 1,2010)$ over de negendelige televisiereeks De Oorlog van schrijver, historicus en programmamaker Ad van Liempt uit 2009. Henkes concludeerde dat het als meerstemmig gepresenteerde 'accomodatiemodel' van de Tv-maker(s) even of mogelijk zelfs meer normatief en ordenend was dan het 'goed' en 'fout' schema uit het TV-werk van De Jong waartegen het zich afzette. De publicatie van Oorlogsouders van Isabel van Boetzelaer toont aan dat dit debat in Nederland maar blijft voortduren. ${ }^{17}$ Tot een algemene bespiegeling over die essentiële spanning kwam het uiteindelijk niet meer in de BMGN. De toenmalige BMGN-redactie week daarna uit naar België om Boudewijn Smits' vuistdikke biografie van Loe de Jong te bespreken. Pieter Lagrou (ULB) wees er onder meer op dat De Jongs neiging tot 'ordening' geplaatst moet worden in de context van de Koude Oorlog in Nederland die voor De Jong de correcte didactische lessen uit het voorbije conflict des te pertinenter maakte.

Dat in dit soort paradigmatische discussies ook de rol van het NIOD ter discussie stond, blijft doorgaans in het verborgene. Het kwam enkel even boven naar aanleiding van het recensieartikel van Hans Blom uit 2005 over het sociaalwetenschappelijke historische onderzoek over de Jodenvervolging (120:4, 2005). Blom ging in hoofdzaak de discussie aan over de manier waarop Marnix Croes en Peter Tammes in hun dubbeldissertatie kwantitatieve methoden gebruikten en hoe zij zich positioneerden tegenover iedereen die dat niet deed - door hen ook wel eens aangeduid als 'de historici'. Blom besloot dat de volgens hem te verkiezen wetenschappelijke vernieuwing toch elders lag. In zijn 'recht van antwoord' maakte Croes met een gezonde dosis zelfvertrouwen meteen de onderzoekspolitiek van het NIOD tot onderwerp van dit debat. ${ }^{18}$

\section{Chaja Polak, De man die geen hekel had aan joden.}

Een botsing met het verleden (Amsterdam 2018).

'Tegelijkertijd blijft het onzeker of de

geschiedschrijvers van de Jodenvervolging in

en rond het NIOD de kant van multidisciplinair onderzoek op zullen gaan. De teneur in Bloms 


\section{Over de onmogelijkheid van Belgische 'Blommianen'}

Al deze debatten zijn op zich begrijpelijk voor Belgische woII-onderzoekers, maar toch blijven zij hier onherroepelijk buitenstaanders. De Belgische paradigmatische krijtlijnen werden na 1945 immers op een heel andere manier getrokken. Toen de wetenschappelijke studie van woII in België eind jaren 1960 langzaam op gang kwam, was de erfenis van deze oorlog al onherroepelijk geassimileerd met de laatnegentiende-eeuwse breuklijnen die België als unitaire staat uiteen trokken. Het terrein was intussen bezet door een pseudowetenschappelijke onderzoekstraditie uit Vlaams-nationale hoek met een grote maatschappelijke invloed. Belgische woII-onderzoekers moesten of konden dus geen 'ordenend' kader creëren: wanneer zij eindelijk op het speelveld kwamen, had die ordening al plaatsgevonden. Dat creëerde als het ware de situatie van een 'gemeenschappelijke vijand' die Belgische woII-historici bij elkaar bracht in een gedeeld mission statement. Die missie kwam eenvoudig neer op het bevechten van de expliciete politieke instrumentalisering van het oorlogsverleden en van de intussen diep gewortelde vijandsbeelden die erdoor werden gecultiveerd. ${ }^{19}$

Om deze politieke verdeeldheid te overstijgen die ook voor de Belgische academische gemeenschap een reële bedreiging kon vormen, vonden Vlaamse en Franstalige woII-historici elkaar in drie essentiële ankerpunten: een rigide archivalische empirie, een objectiverende methodologie die soms ontleend werd aan de sociale wetenschappen en moeizaam ontwikkelde mechanismen om onderling consensus te bereiken. Geen polarisering of felle debatten in België dus, wel integendeel. Meerdere factoren speelden daarbij een rol. In de Belgische geschiedschrijving was de Jodenvervolging bijvoorbeeld decennialang geen belangrijk thema, waardoor het debat over historisch moralisme nooit zo acuut was als in Nederland. Een ander verschilpunt is dat in België geen equivalent bestaat van de Nederlandse inaugurale redes waarmee strategische richtinggevende standpunten gelanceerd worden. In meer algemene zin zegt het wellicht ook iets over de verschillen in de Belgische-Nederlandse debatcultuur.

Hoe het ook zij, na het einde van de Belgische unitaire staat in 1993 werd de onuitgesproken wens om het beeld van onderlinge academische consensus naar buiten toe te projecteren alleen maar sterker. Het leidde tot een situatie waarin een consensus over het richtinggevende paradigma eerder stilzwijgend tot stand kwam, waarin potentiële wetenschappelijke onenigheid weinig ademruimte kreeg en waarin gehanteerde definities beeld- en mythevorming waren 'het katholiekfascistoïde Vlaanderen waarin een meerderheid de collaboratie steunde' en 'de francofone Belgische staat die via een politieke justitie de democratische Vlaamse beweging had willen uitschakelen'. Nico Wouters, 'Veilig Verleden? De herinnering aan de Tweede Wereldoorlog in België', in: Nulpunt 1945. De Lage Landen een mensenleven later (Rekkem 2020) 17-24. 
van bepaalde begrippen in grote mate onuitgesproken bleven, en dus voor buitenstaanders moeilijk te vatten waren. Ook al bedoelen Belgische en Nederlandse woII-experts met bijvoorbeeld de term 'accommodatie' in historische zin zo ongeveer hetzelfde, het wetenschappelijke debat hierover verliep helemaal anders. De uiteenlopende betekenislagen en de specifieke gevoeligheden van dezelfde begrippen kunnen gemakkelijk leiden tot twee verschillende gesprekken.

Een ander aspect dat in ditzelfde kader vermelding verdient, is de moeilijkheid om Franstalige auteurs te engageren in de BMGN. Veel Belgisch woII-pioniersonderzoek in de jaren 1970-1980 was de verdienste van Franstalige onderzoekers die vaak op de Franse of Franstalige onderzoekcultuur waren georiënteerd. Blom riep in zijn oratie uit 1983 bijvoorbeeld op om wat de Joodse mortaliteit betrof de Nederlandse specificiteit in een internationaal perspectief te onderzoeken. Dat zou op dat moment voor België lastig zijn geweest. De academische pionier voor het onderzoek naar de Shoah in België was Maxime Steinberg (ULB) die pas in 1986 de publicatie van zijn doctoraat voltooide en haast uitsluitend in het Frans schreef en debatteerde. Een auteur zoals Steinberg betrekken in een BMGN-debat over de Shoah in de 'Lage Landen' zou in 1980-1990 dus een bijzondere inspanning hebben gevergd.

Die Vlaams-Waalse regionalisering bleek echter nooit een obstakel voor een nationale Belgische woII-onderzoekscultuur. In een context waar de politieke en communautaire tegenstellingen via de regionaal sterk uiteenlopende oorlogsherinnering telkens bewust werden opgepookt, ging veel energie naar het in stand houden van de Vlaams-Franstalige dialoog onder academici. Maar die communautarisering van het woII-onderzoek kan wel mee verklaren waarom niet elk Belgisch onderzoek zich even gemakkelijk in een kader van de 'Lage Landen' liet plaatsen. In Nederland kan de oorlog misschien wel een nationale herinnering 'schragen' (naar de woorden van Niek van Sas), in België kostte alleen al het basisonderhoud van de vermolmde schragen van het nationaal bewustzijn een permanente inspanning. Een beter begrip van deze specifieke kenmerken van het Belgische en van het Nederlandse woIIonderzoeksveld kan belangrijk zijn voor zinvolle toekomstige uitwisseling.

\section{Vooruitblikken}

Dit alles betekent uiteraard niet dat er tot nu toe geen 'echte' uitwisseling plaatsvond in de BMGN. Een mooi voorbeeld is het themanummer (124:3, 2009) over het door Nwo gefinancierde onderzoek 'erfenissen van de collaboratie'. In hun inleiding betrekken de toenmalige BMGN-redacteuren Ido de Haan en Peter Romijn zowel het Belgische als het Nederlandse onderzoeksveld. Ze wijzen op de in beide landen trage ontvoogding van het onderzoek over de collaboratie en de naoorlogse integratie van 
collaborateurs: in Vlaanderen omwille van de politieke instrumentalisering en in Nederland door de pathologisering van de collaboratie. Een ander mooi voorbeeld is het discussiedossier over het politiebestel in de negentiende en twintigste eeuw $(123: 3,2008)$ naar aanleiding van het grootschalige onderzoek onder leiding van Cyrille Fijnaut. Het dossier behandelde een veel ruimere periode, maar kreeg omwille van het belang van Rauters politiehervorming tijdens de Tweede Wereldoorlog toch een belangrijke woII-component. ${ }^{20}$ Vooral het commentaar van Rudi Van Doorslaer, de toenmalige directeur van het Brusselse soma, leidde tot een echte comparatieve reflectie. Ook in het discussiedossier over Martin Conways The Sorrows of Belgium (129:4, 2014) zitten voor de Lage Landen relevante transnationale bespiegelingen. Nele Beyens wijst op een zekere teleologische tunnelvisie in dit boek over het naoorlogse herstel in België die door een meer internationale vergelijking ondervangen had kunnen worden. Mark Mazower heeft kritiek op het gebruik van een begrip als 'de elites' in Conways analyse van verschuivende machtsrelaties na woII, maar is het wel eens met de auteur dat het Belgische systeemherstel een door een conservatieve elite gestuurd proces was.

Ook in meer algemene zin geeft het hoge aantal historiografische en reviewartikelen over woII van Nederlandse auteurs tal van interessante insteken voor een Belgische toepassing. In een belangrijk artikel over de historiografie van de Jodenvervolging (123:1, 2008) gaat Ido de Haan veel verder dan een beargumenteerd literatuuroverzicht. Hij analyseert het interne proces van dialectische voortgang in deze geschiedschrijving en evalueert ook de sterke en zwakke punten van de nieuwe generatie aan onderzoek. Ook het reviewartikel van Jan Bank (110:2, 1995) over de historiografie van de schrijverswereld tijdens woII waarin hij de studies van literatuurhistoricus Piet Calis en de controversiële publicist Adriaan Venema in kritisch perspectief plaatst, bevat voor Belgische onderzoekers bruikbare opmerkingen.

Vooruitblikkend op nog eens vijftig jaren BMGN lijkt het me goed om tot slot ook zelf enkele sporen van meer Belgisch-Nederlandse uitwisseling te suggereren, hoe vrijblijvend en algemeen ook. Die uitwisseling zal naar ik meen in eerste instantie niet liggen in het comparatief naast elkaar zetten van klassieke themastudies over bijvoorbeeld collaboratie, Jodenvervolging of verzet. Het risico dat we daar niet voorbij het myopisch afvinken van overeenkomsten en verschillen geraken is groot. Ik suggereer drie sporen voor uitwisseling die enigszins voor de hand liggen: de methodologische reflectie vanuit de grote archiefcollecties, het radicaal opengooien van de chronologie en het historiseren van de studie van collectieve herinnering. 
Archieven vormen een eerste evident spoor. De Tweede Wereldoorlog creëerde unieke en soms seriële bronnencorpora die ondanks de nationale verschillen ook overeenkomsten vertonen. Het meest voor de hand liggende voorbeeld is het archief van het Militair Gerecht voor de naoorlogse bestraffing van collaboratie in het Rijksarchief van Brussel en het Centraal Archief Bijzondere Rechtspleging in Den Haag. Vragen over hoe deze justitiële bronnen kunnen gebruikt worden voor bijvoorbeeld een sociale geschiedenis, is een vraag waarrond een relevante methodologische uitwisseling kan worden opgezet. Een even voor de hand liggend voorbeeld is het genre van de oorlogsdagboeken in de beide landen. Voor België liggen door de late start van het Navorsings- en Studiecentrum van de Geschiedenis van de Tweede Wereldoorlog (NSGWO) in 1967 en door de late overdrachten na het jaar 2000 naar het Rijksarchief van enkele grote reeksfondsen nog belangrijke collecties te wachten op het eerste fundamenteel onderzoek en het is voor mij interessant te horen of dat voor Nederland ook zo is, en indien niet, hoe de bronnenontsluiting dan wel in relatie stond tot de voortgang van het fundamenteel onderzoek in bepaalde domeinen. ${ }^{21}$

Ten tweede ligt een radicale chronologische verruiming voor de hand. Waar België tijdens de Eerste Wereldoorlog een Duitse bezetting meemaakte, bleef Nederland neutraal. En waar Nederlands-Indië in 1941-1942 eerst door Japan werd veroverd om na het einde van woII meteen meegesleurd te worden in een jarenlange bloedige onafhankelijkheidsoorlog, bleef Belgisch-Congo grotendeels van oorlogsgeweld gespaard en kwam de onafhankelijkheid er pas tijdens de piek van de Koude Oorlog (1960-1961). En in 1944 klonken België en Nederland zich ook aan elkaar in een douane-unie. Die langere geschiedenis plaatst woII met beide voeten in de studie van internationale relaties en de diplomatie, van de uitbouw en neergang van de Fordistische regulering en de Keynesiaanse staat, maar ook van verschuivende politieke en sociale machtsrelaties in de massademocratie, de kolonisering en dekolonisering en daarmee dus ook van vragen over economische uitbuiting en staatsgeweld. ${ }^{22}$ Nadenken over hoe zo'n verruimd kader mogelijk kan zijn archiefcollecties in België de diverse debatbijdragen in het dubbelnummer ' 75 jaar geschiedenis van de Tweede Wereldoorlog in België/75 ans d'histoire de la Seconde Guerre mondiale en Belgique/75 years of Second World War history in Belgium', Belgisch Tijdschrift voor Nieuwste Geschiedenis XLIX:2-3 (2019). (de)kolonisering elkaar eenmaal expliciet in Joop de Jongs antwoord op het stuk van de Amsterdamse politicoloog Jos de Beus ('God dekoloniseert niet'), een debat dat - opnieuw in hoofdzaak draait rond waardeoordelen in historisch onderzoek. Joop de Jong, 'Tussen Shoah en koloniaal verleden', BMGN 116:3 (2001) 330-333. DOI: https://doi.org/10.18352/bmgnIchr.5501; Jos de Beus, 'God dekoloniseert niet. Een kritiek op de Nederlandse geschiedschrijving over de neergang van Nederlands-Indië en Nederlands Suriname', BMGN 116:3 (2001) 307-324. DOI: http://doi. org/10.18352/bmgn-lchr.5499. 
en wat dat voor de studie van woII zou betekenen, kan in het kader van de Lage Landen tot betere inzichten leiden.

Tot slot lijkt het mij ook belangrijk na te denken over de toekomstige condities van de wetenschappelijke studie van de collectieve herinneringen over WoII. In België zagen we na 1995 een sterke groei van een divers aantal woII-publicaties dat expliciet een 'herinneringsdimensie' integreerde. Het ging vaak om niet-academische publicaties die het verleden van woII wilden actualiseren binnen de context van een hedendaagse boodschap. Op zich is die diversiteit heel mooi, maar door deze aangroei van veelgelezen publicaties die het soms niet zo nauw nemen met duidelijk omschreven concepten en vraagstellingen raakte een zekere conceptuele dubbelzinnigheid ingeburgerd. Een term als 'collectieve herinnering' wordt vandaag soms met een lichtzinnigheid gebruikt die voor andere wetenschappelijke termen niet aanvaard zou worden. Claims over hoe bepaalde sociale groepen omgingen met het bezettingsverleden worden soms gelanceerd zonder daarvoor harde onderzoekdata als bewijs te leveren.

De grote Belgisch-Nederlandse verschillen in de naoorlogse verwerking van woII hoeft de wederzijdse methodologische reflectie over het onderzoek naar collectieve herinneringen en de bronnen ervan helemaal niet in de weg te staan. Nadenken over hoe je de studie van 'collectieve herinnering' opnieuw kan vastgrijpen, is overigens niet enkel wetenschappelijk nuttig. Het kan ons eventueel ook deels een uitweg bieden uit de bovenvermelde debatten over de relatie tussen onderzoekresultaten en de 'morele oordelen' die daaruit kunnen worden getrokken. woII-experten worden vandaag vaak in een publieke arena gegooid waar zonder veel scrupules vage en inwisselbare begrippen worden gehanteerd. Meester blijven van je boodschap is in zo'n context moeilijk en kan ook onder collega's tot misverstanden leiden. Enkel al die onderlinge ervaringen uitwisselen, kan naast therapeutisch misschien ook leerrijk blijken.

Gemakkelijker gezegd dan gedaan en in elk geval nog werk genoeg, ook voor de BMGN.

\footnotetext{
Nico Wouters is hoofd van het Studiecentrum Oorlog en Maatschappij (CegeSoma) van het Rijksarchief in België. Hij is gastdocent bij de Universiteit Gent en co-hoofdredacteur van het Belgisch Tijdschrift voor Nieuwste Geschiedenis. $\mathrm{Hij}$ is een specialist van de geschiedenis van woll en de herinneringspolitiek. E-mail: nico.wouters@arch.be.
} 
